\title{
Relationship between insulin administration and substrates oxidation during continuous aerobic exercise in adolescents with type 1 diabetes mellitus
}

\author{
Juliana Pereira Decimo*, Luís Paulo Gomes Mascarenhas, Valderi de Abreu de Lima, Camilla Kapp Fritz, \\ Andréia Araujo Porchat de Leão, Neiva Leite, Luiz de Lacerda Filho, Suzana Nesi França
}

From 20th Brazilian Diabetes Society Congress

Porto Alegre, Brazil. 11-18 November 2015

\section{Background}

The risk of hypoglycemia during and after exercise is a limitation to regular practice. In type 1 diabetes patients.

\section{Objective}

To compare the influence of different intervals of insulin administration, to identify the proportion of oxidized energy substrates at different times of continuous aerobic exercise and evaluate the relationship between oxygen uptake and glycemic variation at the end of the exercise.

\section{Materials and methods}

Six patients with type 1 diabetes mellitus were evaluated: 6 pubertal, BMI Z-score $0.56 \pm 0.48$; chronological age $13.7 \pm 2.6 y$; duration of disease $6.5 \pm 4.26$; mean HbA1c $9.13 \pm 1.7 \%$. Patients took breakfast and insulin at the clinic (mean basal insulin $0.47 \pm 0.07 \mathrm{U} / \mathrm{kg} / \mathrm{d}$ and fast insulin $0.33 \pm 0.12 \mathrm{U} / \mathrm{kg} / \mathrm{d}$ ). Continuous ergometric test at moderated intensity $(60 \% \mathrm{VO} 2 \mathrm{max})$ was performed for $30 \mathrm{~min}$, one and two h after insulin (T1 and T2).
Intensity was controlled through oxidation and heart rate measured at 10 and 30 min of exercise with $K 4 \mathrm{~b} 2^{\circledR}$ gas analyzer. Blood glucose levels were measured at the beginning, 10 and $30 \mathrm{~min}$.

\section{Results}

Initial blood glucose was $299 \pm 48 \mathrm{mg} / \mathrm{dL}, \mathrm{VO} 2 \max$ $40.7 \pm 9.63 \mathrm{ml} / \mathrm{Kg} / \mathrm{min}$. No difference was found between intervals of insulin administration regarding the oxidation of substrates (Figure 1). Difference between 10 and 30 min of exercise are shown in Figure 2. The glycemic variation (VG) was $-65.41 \mathrm{mg} / \mathrm{dL}$. Regression analysis showed correlation $(\mathrm{r}=0.98)$ between glycemic variation, fast insulin and $\mathrm{VO} 2 \mathrm{max}$ with a $\mathrm{R} 2=0.977$, predictive equation: $\mathrm{VG}=347.108-(5.269 * \mathrm{VO} 2 \mathrm{max})-(579.49 *$ fast insulin).

\section{Conclusion}

Substrate oxidation wasn't influenced by insulin administration before exercise. A higher carbohydrate oxidation

\begin{tabular}{l|cccc}
\hline & $\mathrm{T} 1$ & $\mathrm{~T} 2$ & $\mathrm{~T}$ & $\mathrm{p}$ \\
\hline $\mathrm{VO}_{2} 60 \%(\mathrm{ml} / \mathrm{Kg} / \mathrm{min})$ & $21.53 \pm 8.5$ & $20.90 \pm 7.3$ & 1.11 & 0.31 \\
Carbohydrate oxidation (\%) & $81.39 \pm 9.4$ & $79.49 \pm 7.9$ & 0.37 & 0.72 \\
Oxidation of fat (\%) & $19.04 \pm 9.5$ & $21.11 \pm 7.0$ & -0.40 & 0.70 \\
Respiratory exchange ratio & $0.94 \pm 0.03$ & $0.93 \pm 0.01$ & 0.92 & 0.40 \\
\hline
\end{tabular}

Figure 1 Oxidation of substrates $1 \mathrm{~h}$ and $2 \mathrm{~h}$ after insulin administration.

\footnotetext{
* Correspondence: julianadecimo@gmail.com
} Universidade Federal do Paraná, Pinhais, Brazil 


\begin{tabular}{l|cccc}
\hline & $10 \min$ & $30 \min$ & $\mathrm{t}$ & $\mathrm{p}$ \\
\hline Blood glucose $(\mathrm{mg} / \mathrm{dl})$ & $310.16 \pm 68.1$ & $247.66 \pm 81.5$ & 4.67 & 0.05 \\
Carbohydrate oxidation (\%) & $85.54 \pm 7.6$ & $77.44 \pm 10.4$ & 4.2 & 0.01 \\
Oxidation of fat (\%) & $14.84 \pm 7.7$ & $23.03 \pm 10.5$ & -4.3 & 0.01 \\
$\mathrm{VO}_{2} 60 \%(\mathrm{ml} / \mathrm{Kg} / \mathrm{min})$ & $21.37 \pm 8.3$ & $21.63 \pm 8.4$ & -0.79 & 0.46 \\
\hline
\end{tabular}

Figure 2 Oxidation of substrates at 10 and 30 min of exercise.

was observed at $10 \mathrm{~min}$ of exercise and subsequent increase in fat oxidation at $30 \mathrm{~min}$. Fast insulin dosis and $\mathrm{VO} 2 \mathrm{max}$ are a good predictor of glycemic variation at the end of continuous moderate aerobic exercise.
- Convenient online submission

- Thorough peer review

- No space constraints or color figure charges

- Immediate publication on acceptance

- Inclusion in PubMed, CAS, Scopus and Google Scholar

- Research which is freely available for redistribution

Submit your manuscript at www.biomedcentral.com/submit 